\title{
The Starunia collections in the Natural History Museum of the National Academy of Sciences of Ukraine in Lviv
} Zbiory staruńskie w Muzeum Przyrodniczym Narodowej Akademii Nauk Ukrainy we Lwowie

\author{
Yuriy M. Chornobay \& Daniel M. Drygant \\ Natural History Museum of the National Academy of Sciences of Ukraine, 18 Teatralna Street, 79008 Lviv, Ukraine, \\ e-mail:yuchor@museum.lviv.net
}
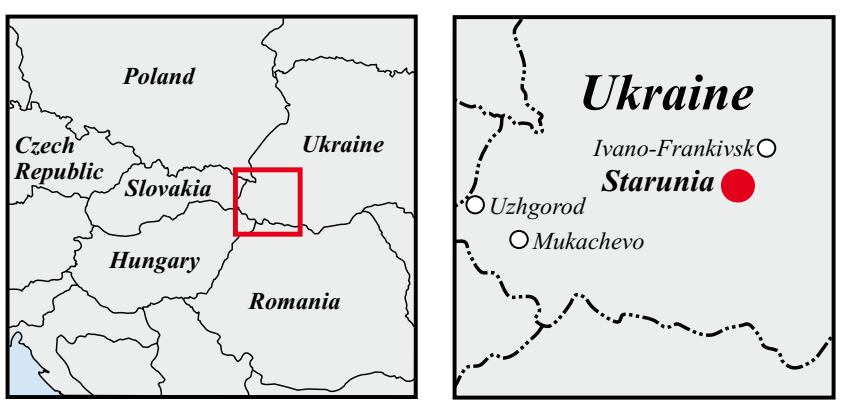

Abstract: In the Natural History Museum of the National Academy of Sciences of Ukraine in Lviv there is a collection of a famous Pleistocene mammoth and a woolly rhinoceros, the so-called "first rhinoceros" from Starunia. The mammoth and the first rhinoceros were found 102 years ago, on 5th October and 6th November, 1907, respectively, in a shaft of an ozokerite (earth wax) mine near Starunia village (the Eastern Carpathians). The discovery of large Pleistocene mammals in Starunia was a spectacular, worldfamous scientific event. Beside the mammoth and the rhinoceros, many specimens of Pleistocene flora and fauna from Starunia and other places of the Fore-Carpathian region are exhibited in the Lviv Natural History Museum.

Key words: Starunia, Lviv Natural History Museum, Ukraine, ozokerite, woolly rhinoceros, mammoth, Pleistocene fauna, Pleistocene flora

Treść: W Muzeum Przyrodniczym Narodowej Akademii Nauk Ukrainy we Lwowie zgromadzono kolekcję szczatków zwiqzanych z odkryciem wspanialych plejstoceńskich okazów mamuta oraz tak zwanego ,pierwszego" nosorożca włochatego. Okazy te znaleziono 102 lata temu, odpowiednio 5 października i 6 listopada 1907 r., w szybie kopalni ozokerytu (wosku ziemnego) w miejscowości Starunia (Karpaty Wschodnie). Odkrycie olbrzymich ssaków plejstoceńskich w Staruni byto sensacja naukowa w skali światowej. Obok mamuta i nosorożca w Lwowskim Muzeum Przyrodniczym znajduja się liczne szczatki flory i fauny roślin i zwierzat doby plejstoceńskiej ze Staruni i innych miejscowości Podkarpacia.

Słowa kluczowe: Starunia, Lwowskie Muzeum Przyrodnicze, Ukraina, ozokeryt, nosorożec włochaty, mamut, fauna plejstoceńska, flora plejstoceńska

Резюме: В Державному природознавчому музеї Національної Академії наук України у Львові зібрані колекиії експонатів, пов'язаних з відкриттям чудово збережених плейстоценових решток мамонта, а також так званого "першого» волохатого носорога. Ці експонати здобуті 102 роки тому, відповідно 5 жовтня і 6 листопада 1907 року в штольні шахти з добування озокериту (підземного воску) поблизу села Старуня (Східні Карпати). Відкриття велетенських плейстоценових ссавців у Старуні було науковою сенсаиією світового масштабу. Разом з мамонтом та носорогом у львівському природознавчому музеї знаходяться численні рештки рослин і тварин плейсточенової доби з Старуні та інших місиь Передкарпаття.

Ключові слова: Старуня, Львівський природознавчий музей, Україна, озокерит, волохатий носоріг, мамонт, плейсточенська фауна, плейстоиенська флора

\section{Introduction}

The State Museum of Natural History (formerly the Dzieduszycki's Family Museum) in Lviv is an important centre for scientific research and belongs to organizational structure of the Department of General Biology of the the National Academy of Sciences of Ukraine (NASU).

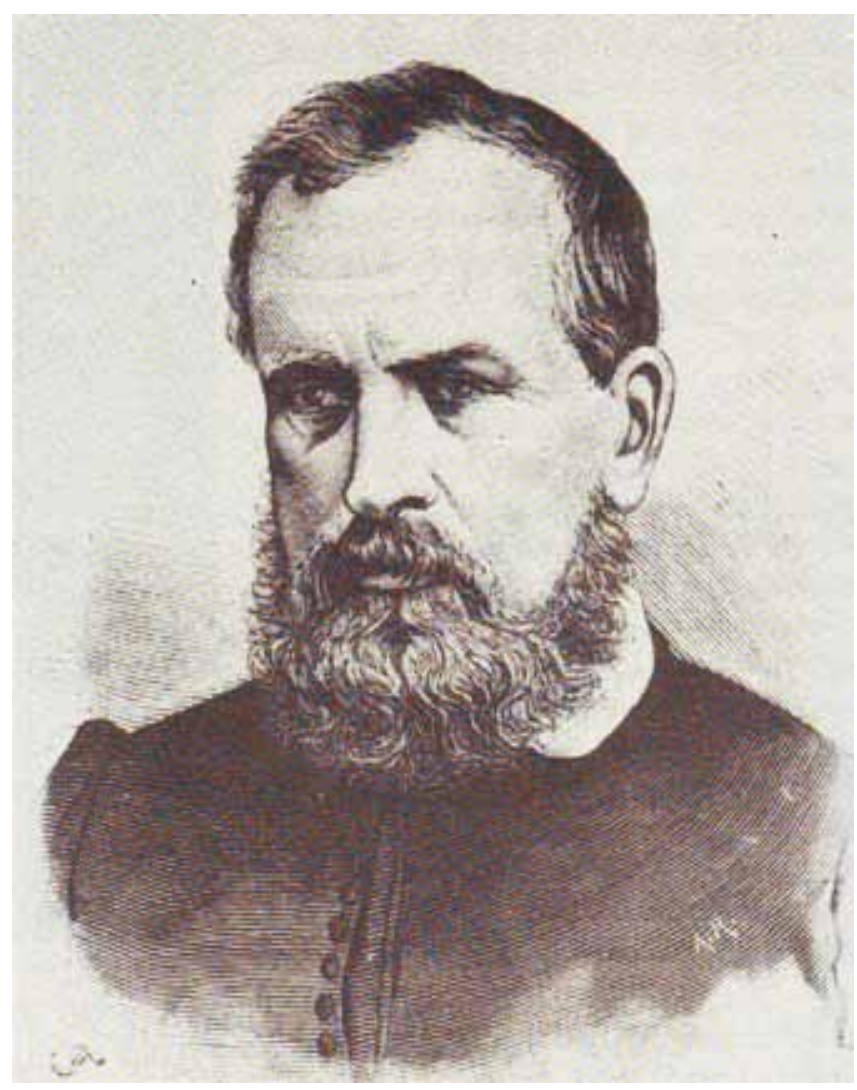

Fig. 1. Count Włodzimierz Dzieduszycki (1825-1899). Portrait by Tytus Maleszewski (about 1865) (Brzęk, 1994) • Hrabia Włodzimierz Dzieduszycki (1825-1899). Portret Tytusa Maleszewskiego (około 1865) (Brzęk, 1994) 
There are many very important specimens in the museum, which are related to the discovery of the mammoth and the woolly rhinoceroses in Starunia, mainly originating from the year 1907. Therefore, the museum is an important element of the planned Starunia (Ukraine) - Kraków (Poland) crossborder geotouristic route "Traces of large extinct mammals, earth wax, oil and salt" (Kotarba, 2009).

\section{History of the Museum}

The State Museum of Natural History of the NASU in Lviv is one of the oldest and the richest scientific collections in Europe. It was founded by count Włodzimierz Dzieduszycki (1825-1899), famous Polish zoologist, ethnographer and archaeologist (Fig. 1). He was a member of the Academy of Arts and Sciences in Kraków (since 1881), and spent a significant part of his fortune on purchasing the exhibits and supporting the museum (Brzęk, 1994). Dzieduszycki, who originated from one of the richest families in Galicia, was interested in science from childhood. He had been collecting specimens of fauna and flora for years, and kept them in Poturzyce (Potorytsya) palace situated about $80 \mathrm{~km}$ north of Lviv (Brzęk, 1994). At the end of the 1840s Dzieduszycki's zoological collection was enriched by paleontological and mineralogical collections of Professor Ludwik Zejszner from the Warsaw University, and by the herbarium of Professor Jan Łobarzew-

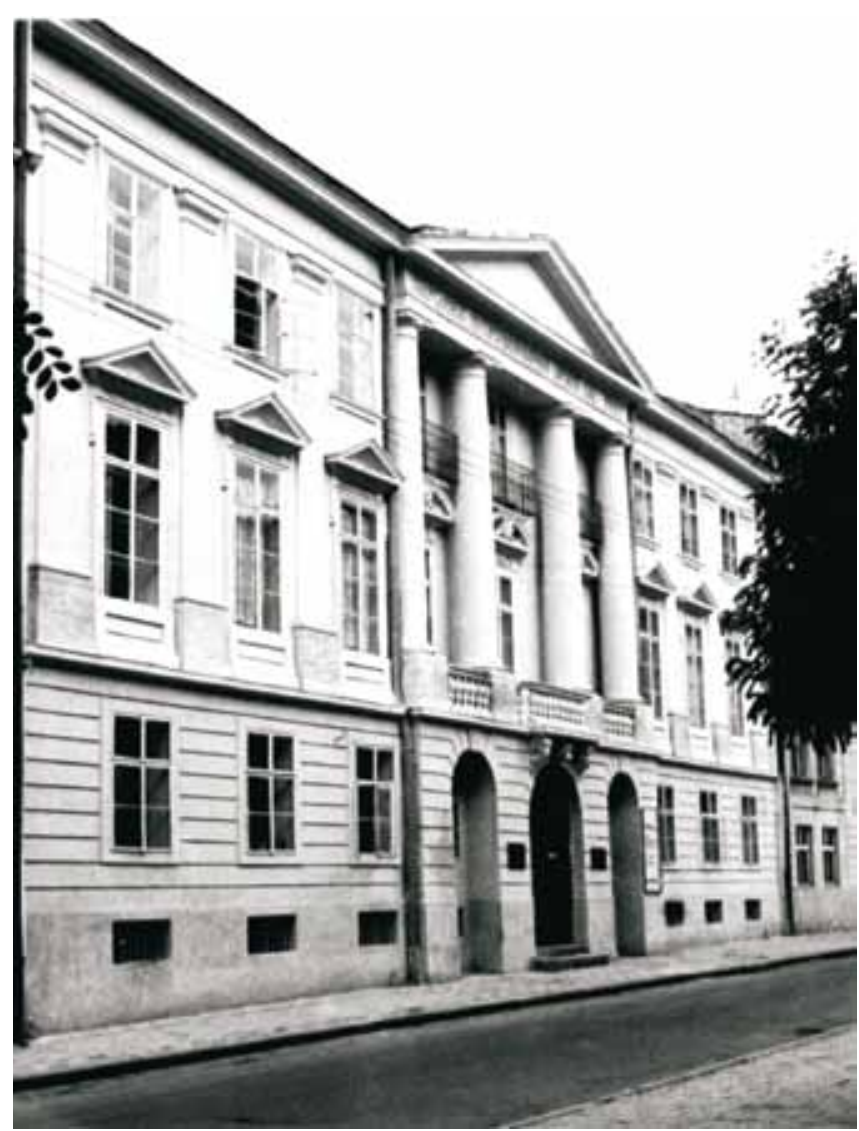

Fig. 2. Present state of the building of the State Museum of Natural History of the National Academy of Sciences of Ukraine (former Dzieduszycki's Family Museum) in Lviv. Phot. V. Vojchyszyn • Obecny stan budynku Państwowego Muzeum Przyrodniczego Narodowej Akademii Nauk Ukrainy we Lwowie (dawniej Muzeum Przyrodniczego im. Dzieduszyckich). Fot. V. Vojchyszyn

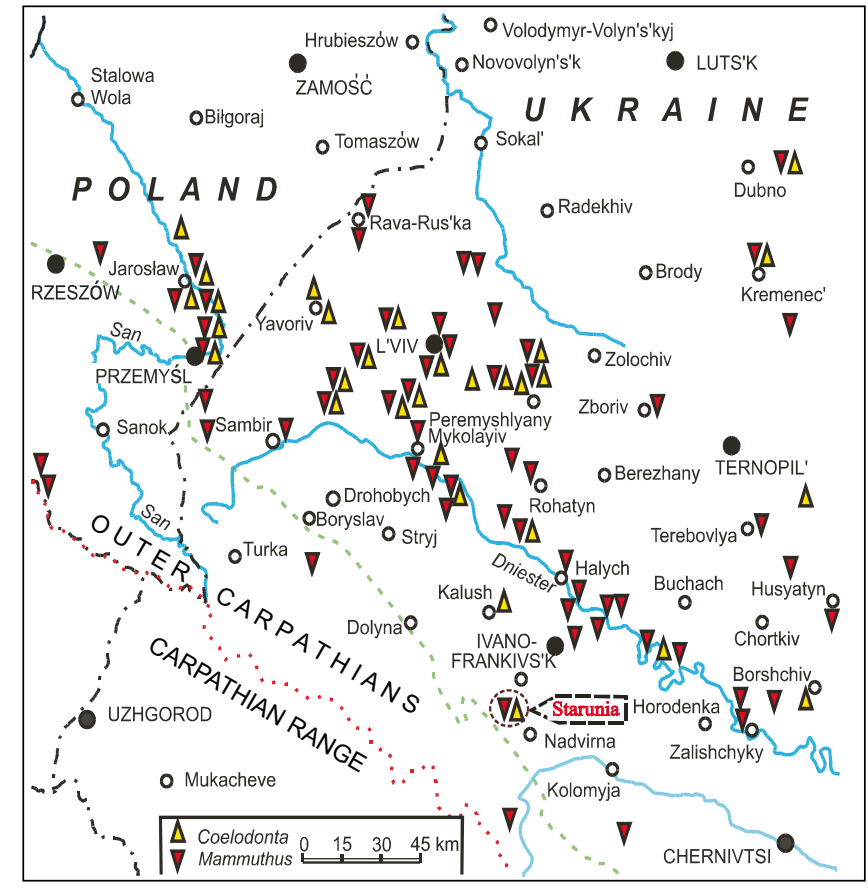

Fig. 3. Localities of mammoths and woolly rhinoceroses remains found in the Fore-Carpathian region. Map from the Archives of the State Museum of Natural History in Lviv • Lokalizacja miejsc odkryć szczątków mamutów i nosorożców włochatych na Przedgórzu Karpat. Mapa z Archiwum Państwowego Muzeum Przyrodniczego we Lwowie

ski from the Lviv University and with some other specimens (Brzęk, 1994). Thus, a decision was made to find a building which could house such a magnificent collection. In 1854 a part of the collection was transported from Poturzyce to Lviv and housed in a building in Fredro Street, and in 1857 it was moved to Dzieduszycki's palace in 15 Kurkowa Street (recently Lysenka Street). As the collection was quickly growing, in 1868 Włodzimierz Dzieduszycki bought a building in 18 Teatralna Street, where the museum still exists (Fig. 2). After renovation of the building in 1869 the whole Dzieduszycki's collection was moved there. The building is a monument of architecture and has the technical marvel - the oldest lift in Europe, produced in Vienna in the middle of the 19 th century. After arranging the exhibition in 1870, only several visitors could attend it. On 13th August, 1872 the museum introduced the Visitors' Book. Since 1873 the museum has been open for visitors once a week. Thus, the year 1870 is considered as the official date of its foundation when the exhibition was available for the public. During Włodzimierz Dzieduszycki's life the exhibition included 7 departments: zoological, paleontological, mineralogical, geological, botanical, archeological and ethnographical. At that time, many scientists were of the opinion that the scientific value of the Dzieduszycki's Family Museum is comparable to that of the London National Museum of the British Royal Society.

On 10th September, 1880 Włodzimierz Dzieduszycki donated the museum to the city and granted the legacy of 12,000 Austrian crowns per year as its financial support. Money originated from the Dzieduszycki's land property in Poturzyce (in Polish: "Ordynacja Poturzycka") officially approved as an impartible real estate by the decision of the 
Parliament in Vienna on 20th December, 1893. Simultaneously, the museum was officially named "The Dzieduszycki's Family Natural History Museum" (in Polish: "Muzeum Przyrodnicze im. Dzieduszyckich"). According to the rules of the Parliament, the member of the Dzieduszycki family who owned the real estate was the owner and the manager of the museum. Włodzimierz Dzieduszycki’s was the first manager.

A new stage in the museum's history started during World War II when, in 1940, it came under the Soviet authority of the Ukrainian SSR Academy of Sciences. The museum acquired the collections of the Natural History Museum of the Shevchenko Scientific Society whereas its own non-natural collections were transferred to other museums in Lviv. At that

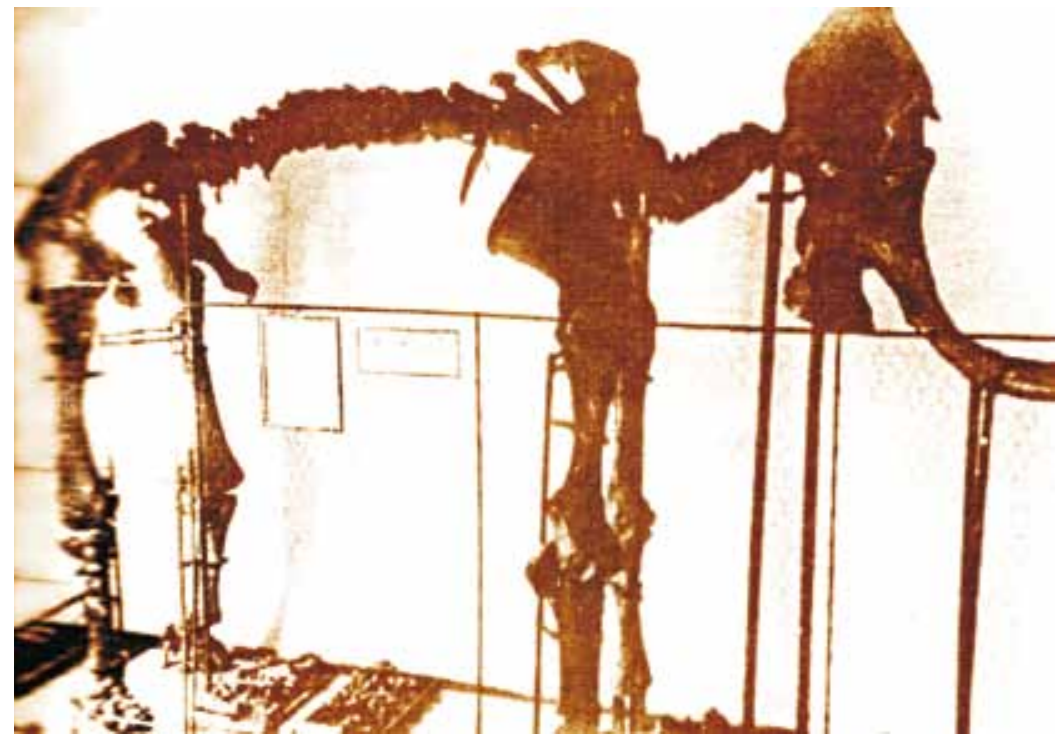
time the museum was renamed "The Scientific Natural History Museum of the Ukrainian SSR Academy of Sciences". It has been the center of scientific research activity, the aim of which was to study flora, fauna and minerals in the Western Ukraine. World War II stopped the scientific activity for a few years. Ceremonial re-opening of its new exhibition took place in February, 1948.

At that time the museum consisted of 3 departments: zoological, botanical, and geological. In 1995 major restoration of the main building has started. Therefore, the exhibition was temporarily closed, dismantled and placed in storage. All this time the museum was arranging touring exhibitions. Today, a new scientific concept and a thematic structure of a new redesigned museum exhibition was been prepared.

\section{Pleistocene fauna of Starunia and other sites in the Fore-Carpathian region exhibited in the State Museum of Natural History in Lviv}

In the Pleistocene the most common large animals in Europe and in Northern Asia were mammoths and rhinoceroses. Their remnants, mainly bones, teeth, tusks and their fragments, occasionally skulls with teeth, were found in many localities in the Fore-Carpathian region (Fig. 3). The State Museum of Natural History NASU (formerly The Dzieduszycki's Family Natural History Museum) occupies a special place as it houses exceptionally valuable findings from Starunia village (Bayger et al., 1914).

The workers of the ozokerite mine in Starunia village, who casually found the carcass of an unknown animal in October 1907, could not even imagine that their finding would be a scientific sensation on global scale. Because the bones of a large ox, as they thought, impeded their work, some part of the carcass was crushed. A few days after, the mine supervisor realized that the bones might have belonged to a mammoth and this information was sent to the Universities in Lviv and Kraków, and to the Polytechnic Institute in Lviv (Alexandrowicz, 2004). A com-

Fig. 4. Mammoth skeleton at the State Museum of Natural History of the National Academy of Sciences of Ukraine in Lviv. Photo from the Archives of this Museum • Szkielet mamuta w Państwowym Muzeum Przyrodniczym Narodowej Akademii Nauk Ukrainy we Lwowie. Fot. Archiwum Muzeum

petent commission then examined the remnants and confirmed the scientific value of the uniquely partly preserved specimen of the Late Pleistocene mammoth species Elephas primigenius (recently: Mammuthus primigenius Blum.). However, the real sensation was that animal's soft tissues and skin were preserved, as well. At the request of the Dzieduszycki's Family Natural History Museum and having the approval of the mine owner, the manager of the mine passed all mammoth remains (bones, skin and tusks) to the Museum (Fig. 4).

Later on, the skeleton was mounted and exhibited as one of the most valuable acquisitions. At that time, Tadeusz Dzieduszycki (1841-1918), son of Włodzimierz, was the owner of the Museum and Marian Łomnicki (1845-1915), Polish zoologist, geologist, paleontologist and famous organizer, and expert of museum management was its director. H. Kubiak (2001) presented: “The mammoth's skeleton consists of: the skull - the upper jaw with both tusks, and the second molars (M2) right and left; the vertebral column - 6 vertebrae of the neck, 14 thoracal vertebrae, and 5 lumbar vertebrae, os sacrum, and 10 vertebrae of the tail; fragments of ribs (14-19); the right scapula; the right ulna and radius; right carpals and phalanges; a fragment of the pelvis; fragments of right femur, tibia and fibula. Not all other parts of this skeleton belong to that specimen found in Starunia. There are also very important soft parts of the Starunia mammoth: cartilage between the vertebras, pieces of flesh, a huge piece of skin (320 x 134 $\mathrm{cm}, 15 \mathrm{~mm}$ thick); in the museum is also stored hair of the mammoth which has been found in the vicinity of the carcass". The publicity given by paleontologists after mammoth's finding caused that further exploitation at the ozokerite mine was carried out with great care in order to avoid occasional missing or damaging of remains of other 


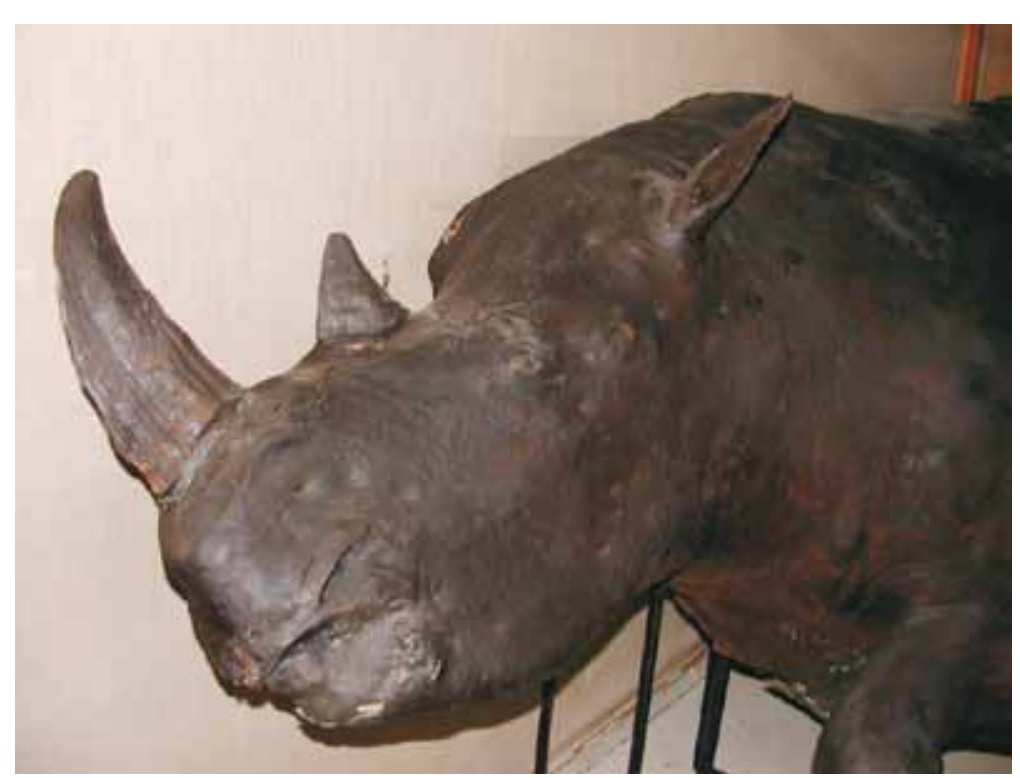

were made by painters basing on the model of the first mounted Starunia's specimen, and its photographs were published in paleontological journals and text-books (Abel, 1922; Müller, 1970). This finding became also a topic of monographs (Kotarba, ed., 2005, 2009) and scientific conferences (Gerlach, 1993; Kubiak, 1994; Chornobay \& Kotarba, eds., 2008). Due to the number and perfect preservation of specimens, Starunia has been enlisted into the group of famous European localities of fauna and flora fossils of top scientific value, together with e.g.: the site of Jurassic fossil birds in Solenhofen (Germany), the site of Cretaceous iguanodonts in Bernissar (Belgium) and the site of Pliocene vertebrates in Pikerm (Greece), which played an important role in extending the knowledge of life history on the Earth.

Fortunately, the collections of the State Museum of Natural History (the successor of the Dziedu-

Fig. 5. Present state of the "first" rhinoceros from the State Museum of Natural History in Lviv. Phot. V. Vojchyszyn $\bullet$ Obecny stan „pierwszego” nosorożca w Muzeum Przyrodniczym Narodowej Akademii Nauk Ukrainy we Lwowie. Fot. V. Vojchyszyn

animals. These measures were not useless - at the beginning of November, 1907 miners found a partly preserved carcass at a depth of $17.6 \mathrm{~m}(5 \mathrm{~m}$ beneath the previous finding of mammoth). This was the so-called "first rhinoceros" of Starunia. The Rhinoceros (recently Coelodonta antiquitatis Blum., colloquially named "woolly rhinoceros") was another extinct representative of Pleistocene fauna. The remains included the head covered with preserved skin, left ear, left fore leg, skin from the fore-part of left side and two horns (anterior and posterior). All excavated remains of this rhinoceros were also passed to the Dzieduszycki Family Museum, where they were conserved, mounted (Fig. 5) and exhibited in the Department of Paleontology together with the skeleton and the skin of mammoth. At the same time, apart from the mammoth and the woolly rhinoceros, the Museum acquired remains of other fossiled animals and plants. The precise age of plant and animal remnants found nearby the mammoth and the woolly rhinoceros is unknown. These probably belong to recent flora and fauna (Szafer, 1930; Granoszewski, 2002).

The paleontological specimens discovered in Starunia village in 1907 were professionally studied and described in detail in the monograph published by the Dzieduszycki Family Museum (Bayger et al., 1914). Owing to this publication, the knowledge of anatomy of extinct mammoth and woolly rhinoceros has become more complete in comparison with previous studies. The search, study and mounting history of Starunia's mammoth and rhinoceros were described in detail by Łomnicki (in: Bayger et al., 1914), Alexandrowicz (2004) and Kubiak \& Drygant (2005).

The next, nearly completely preserved rhinoceros was found in Starunia in 1929 (Nowak et al., 1930). This specimen is now displayed at the Museum of Natural History in Kraków, Poland (Kubiak, 2009; Kubiak \& Drygant, 2005). It should be noted that the first pictures of "natural" woolly rhinoceros szycki Family Museum) not only have survived the periods of two world wars without any loss or damage, but also have increased considerably. During World War II (in 1940) the collection of Quaternary fauna was supplied by valuable specimens from the Geological Museum of the Scientific Society (named in honor of T. Shevchenko after it was abolished by the Soviets). After World War II the collection was again extended at the effort of the staff and other persons. The number of remains of Quaternary fauna acquired by the museum during the century since the unique discoveries in Starunia, have already exceeded several thousands. These include numerous fragments of mammoth and rhinoceros skeletons (crania, tusks, teeth and bones) from more than 100 localities in the Fore-Carpathian region (Fig. 3).

\section{Conclusions}

The State Museum of Natural History in Lviv is ranked among the most interesting and richest natural museums in Europe. It possesses unique remains of ancient and recent fauna and flora. The most famous items are: a partial well -preserved skeleton of mammoth with soft tissues, front part of a woolly rhinoceros and other Pleistocene flora and fauna fossils.

The paleontological specimens collected at the museum were identified and studied by specialists. These specimens essentially enriched the knowledge of anatomy, ontogenesis and variability of mammoth and rhinoceros as well as the taxonomic diversity of fauna and flora specimens which are indicative of Pleistocene paleogeographical conditions in the Carpathian region.

Acknowledgements. Review comments and suggestions by Stefan W. Alexandrowicz of the Polish Academy of Arts and Sciences in Kraków and Henryk Kubiak of the Polish Academy of Sciences in Kraków were very helpful. We would like to express our gratitude to John Curtis of the Colorado School of Mines in Golden and Maciej J. Kotarba of the AGH University of Science and Technology in Kraków for their critical comments, which improved this paper. 


\section{Streszczenie \\ Zbiory staruńskie w Muzeum Przyrodniczym Narodowej Akademii Nauk Ukrainy we Lwowie}

\section{Yuriy M. Chornobay \& Daniel M. Drygant}

Państwowe Muzeum Przyrodnicze Narodowej Akademii Nauk Ukrainy (NANU) we Lwowie jest jednym z najstarszych i najbogatszych muzeów przyrodniczych w Europie. Zostało ono założone przez hrabiego Włodzimierza Dzieduszyckiego (1825-1899), sławnego polskiego zoologa, etnografa i archeologa (Fig. 1). Od r. 1881 był on członkiem -korespondentem Akademii Umiejętności w Krakowie i wydał znaczną część swoich dochodów na zakup nowych okazów i utrzymanie muzeum. Hrabia Dzieduszycki, który należał do jednej z najbogatszych rodzin w Galicji, od najmłodszych lat interesował się naukami przyrodniczymi. Kolekcję fauny i flory umieścił w pałacu w Poturzycach, który był usytuowany około $80 \mathrm{~km}$ na północ od Lwowa.

W 1854 r. część kolekcji została przetransportowana z Poturzyc do Lwowa i umieszczona w budynku przy ulicy Fredry, a od r. 1857 znalazła się w pałacu Dzieduszyckich przy ulicy Kurkowej 15 (współcześnie ulica Lysenka). Kolekcja ta została szybko wzbogacona o nowe okazy, dlatego w roku 1868 Włodzimierz Dzieduszycki zakupił budynek przy ulicy Teatralnej 18, w którym muzeum znajduje się do dzisiaj (Fig. 2). Ekspozycję utworzono w roku 1870, a od roku 1873 muzeum było otwarte dla zwiedzających raz w tygodniu. W tym czasie muzeum składało się z 7 oddziałów: zoologii, paleontologii, mineralogii, geologii, botaniki, archeologii i etnografii. Dnia 10 września 1880 roku Włodzimierz Dzieduszycki podarował muzeum miastu. 20 grudnia 1893 roku Parlament we Wiedniu zatwierdził „Ordynację Poturzycką”. Od tego czasu Muzeum nosiło oficjalną nazwę ,Muzeum Przyrodnicze im. Dzieduszyckich”. Zgodnie z „Ordynacją Poturzycką" członkowie rodziny Dzieduszyckich, tak zwani „ordynaci”, stali na czele muzeum i zarządzali jego mieniem.

Nowy etap w historii muzeum rozpoczął się w 1940 roku, kiedy przeszło ono pod władzę Akademii Nauk Ukraińskiej Republiki Sowieckiej. W latach 1941-1944, podczas okupacji niemieckiej, muzeum było zamknięte. Uroczystość otwarcia Państwowego Muzeum Przyrodniczego Narodowej Akademii Nauk Ukrainy miała miejsce w lutym 1948 roku. Muzeum składało się z 3 oddziałów: zoologicznego, botanicznego i geologicznego. W 1995 roku rozpoczął się remont głównego budynku muzeum, który trwa do dzisiaj.

Szczątki mamutów i nosorożców włochatych, głównie kości, zęby, ciosy i ich fragmenty, są znane z wielu miejsc na Przedgórzu Karpat (Fig. 3). W Muzeum Przyrodniczym we Lwowie znajduje się kolekcja szczątków związanych z odkryciem wspaniałych plejstoceńskich okazów mamuta (Mammuthus primigenius Blum.) i tak zwanego ,pierwszego" nosorożca włochatego (Coelodonta antiquitatis Blum.). Okazy te znaleziono odpowiednio 5 października i 6 listopada 1907 r. w szybie kopalni ozokerytu w miejscowości Starunia (Karpaty Wschodnie). Odkrycie olbrzymich ssaków plejstoceńskich w Staruni było sensacją naukową na skalę światową. H. Kubiak tak opisał szczątki mamuta ze Staruni znajdujące się w Muzeum Przyrodniczym im Dzieduszyckich we Lwowie (Fig. 4): „Ze szkieletu mamuta ze Staruni zachowały się następujące elementy: górna szczęka z obydwoma siekaczami (ciosami) oraz zębami trzonowymi (M2) prawym i lewym; kręgosłup: 6 kręgów szyjnych, 14 kręgów piersiowych, 5 kręgów lędźwiowych, kość krzyżowa, 10 kręgów ogonowych; fragmenty żeber (14-19); prawa łopatka; kości prawej kończyny przedniej: łokciowa i promieniowa oraz kości nadgarstka; fragment miednicy; fragmenty kości prawej kończyny tylnej: udowej, goleniowej i strzałkowej oraz kości stępu. Wszystkie inne wyżej nie wymienione elementy zmontowanego szkieletu mamuta nie należą do osobnika znalezionego w Staruni. Zachowały się także bardzo ważne tkanki miękkie mamuta ze Staruni: chrząstka i więzadła przy kręgach; fragmenty mięśni; duży płat skóry (320 x $134 \mathrm{~cm}$, o grubości 1,5 cm); oraz przechowywane również w Muzeum włosy mamuta znalezione w bezpośrednim sąsiedztwie wyliczonych powyżej szczątków".

Szczątki „pierwszego" nosorożca ze Staruni składaja się z głowy pokrytej skórą z zachowanym lewym uchem, zachowaną lewą przednią nogą, skórą z przedniej części lewej strony ciała i dwóch rogów. Wszystkie odkryte szczątki nosorożca zostały zakonserwowane i wystawione w Oddziale Paleontologicznym Muzeum Przyrodniczego im. Dzieduszyckich (Fig. 5) wraz ze szkieletem i skórą mamuta. W tym samym czasie, oprócz mamuta i nosorożca, w Muzeum znalazły się zachowane szczątki innych zwierząt oraz roślin prawdopodobne plejstoceńskich, znalezione także w kopalni ozokerytu w Staruni. W 1929 r. w Staruni znaleziono unikatowy, prawie w pełni zachowany okaz „drugiego” nosorożca włochatego, który obecnie znajduje się w Muzeum Przyrodniczym w Krakowie. Liczba i dobry stan zachowania szczątków plejstoceńskich zwierząt i roślin pozwalają zaliczyć Starunię do europejskich stanowisk paleontologicznych o ogromnej wartości, podobnie jak stanowisko jurajskich ptaków kopalnych w Solenhofen (Niemcy), stanowisko kredowych iguanodontów w Bernissar (Belgia) i stanowisko plioceńskich kręgowców w Pikerm (Grecja).

Kolekcja szczątków znaleziska w Staruni w roku 1907 znajdująca się w Muzeum Przyrodniczym we Lwowie jest ważnym elementem planowanej ukraińsko-polskiej trasy geoturystycznej „Śladami olbrzymich wymarłych ssaków, ropy naftowej i soli” biegnąca od Staruni do Krakowa. 


\section{References (Literatura)}

Abel, O., 1922. Lebensbilder aus der Tierwelt der Vorzeit. Verlag von Gustav Fischer, Jena, $643 \mathrm{pp}$.

Alexandrowicz, S.W., 2004. Starunia i badania czwartorzędu w tradycji i inicjatywach Polskiej Akademii Umiejętności. Studia i materiały do dziejów PAU, 3: 261 pp. (In Polish only)

Bayger, J.A., Hoyer, H., Kiernik, E., Kulczyński, W., Łomnicki, M., Łomnicki J., Mierzejewski, W., Niezabitowski, E., Raciborski, W., Szafer, W. \& Schille, F., 1914. Wykopaliska staruńskie. Słoń mamut (Elephas primigenius Blum.) i nosorożec włochaty (Rhinoceros antiquitatis Blum. s. tichorhinus Fisch.) wraz z współczesną florą i fauną. Muzeum im. Dzieduszyckich we Lwowie, 15, 386 pp + atlas (67 tab.). (In Polish only)

Brzęk, G., 1994. Muzeum im. Dzieduszyckich we Lwowie i jego twórca Wydawnictwo Lubelskie Nowe, Lublin.

Chornobay, Y.M. \& Kotarba, M.J. (eds), 2008. Przyrodniczo-historyczna spuścizna Staruni. Materiały II Międzynarodowej konferencji naukowej z okazji 100-rocznicy znalezienia mamuta i pierwszego nosorożca włochatego w Staruni w 1907 roku. Starunia - Lviv - Ivano-Frankivsk - Kraków, 15-17 maja 2008, 194 pp. [in Ukrainian and Polish].

Gerlach, T., 1993. Konferencja z okazji 85-lecia znalezisk paleontologicznych w Staruni na Przedkarpaciu. Przegląd Geograficzny, 65: 243-244.

Granoszewski, W., 2002. Szczątki roślinne towarzyszące wykopaliskom mamuta i nosorożca włochatego w Staruni (Ukraina) w latach 1907 i 1929. Wiadomości Botaniczne, 46 (3-4): 29-34.

Kotarba, M.J. (ed.), 2005. Polish and Ukrainian geological studies (20042005) at Starunia - the area of discoveries of woolly rhinoceroses. Polish Geological Institute and Society of Research on Environmental Changes "Geosphere", Warszawa-Kraków, 218 pp.

Kotarba, M.J., 2009. The Starunia palaeontological site and idea of Ukrainian-Polish trans-border geoturist trail "Traces of large, extinct mam- mals, earth wax, oil and salt: from Starunia to Kraków”. Geoturystyka, This volume.

Kotarba, M.J. (ed.), 2009. Interdisciplinary studies (2006-2009) at Starunia (Carpathian region, Ukraine) - the area of discoveries of woolly rhinocerouses. Annales Societatis Geologorum Poloniae, 79 (3): 217-480.

Kubiak, H., 1994. Starunia - w 85 rocznicę pierwszych odkryć paleontologicznych. Wszechświat, 95: 295-299. (In Polish only)

Kubiak, H., 2001. Unique preservation of mammoth carcass. Proceedings of the 1st International Congress "The World of Elephants”, Roma, 376 pp.

Kubiak, H., 2009. The Starunia collections in the Institute of Systematics and Evolution of Animals, Polish Academy of Sciences in Kraków. Geoturystyka, This volume.

Kubiak, H. \& Drygant, D.M., 2005. The Starunia collections in Lviv and Kraków natural history museums and history of palaeontological studies. In: M. J. Kotarba (ed.) - Polish and Ukrainian geological studies (20042005) at Starunia - the area of discoveries of woolly rhinoceroses. Polish Geological Institute and Society of Research on Environmental Changes "Geosphere", Warszawa-Kraków: 37-44.

Müller, A.H., 1970. Lerbuch der Paläozoologie. G. Fischer Verlag, Jena. 3. Vertebraten. Teil 3. Mammalia, $855 \mathrm{pp}$.

Nowak, J., Panow, E., Tokarski, J., Szafer, W. \& Stach, J., 1930. The second woolly rhinoceros (Coelodonta antiquitatis Blum.) from Starunia, Poland. Bulletin Internationale de l' Académie Polonaise des Sciences et des Lettres de Cracovie, B: 1-47.

Szafer, W., 1930. The Diluvial Flora in Starunia. In: Nowak, J., Panow, E., Tokarski, J., Szafer, W. \& Stach, J. (eds.) - The second woolly rhinoceros (Coelodonta antiquitatis Blum.) from Starunia, Poland. Bulletin International de l'Académie Polonaise des Sciences et des Lettres de Cracovie, Ser. B, Cracovie: 12-21. 